\title{
Regenerating eastern white pine: A cooperative research approach
}

\author{
by D. Burgess ${ }^{1}$, S. Wetzel ${ }^{2}$ and F. Pinto ${ }^{3}$
}

\begin{abstract}
A 27-ha field study was set up in 1994 within the Petawawa Research Forest near Chalk River, Ontario with input and support from local research scientists, forest managers and forest technicians. The study was designed to examine the effects of partial cutting, site preparation and underplanting in natural eastern white pine (Pinus strobus L.) stands. A complete randomized block experimental design was followed with four replicates. Three thinning (control, one-crown and two-crown spacing) and four site preparation (control, scarification, brush control using herbicide, and both scarification and brush control using herbicide) treatments were applied. Natural regeneration and planted seedling survival and growth, soil nutrient availability and other environmental factors are being monitored and recorded. Early results have contributed to the development of a new provincial silvicultural guide and a prototype expert decision support system for white pine management. Research activities are evaluated and coordinated with field practices each year through the development of formal collaborative agreements, meetings, joint workshops and field tours. On-site staff is helping to collect field data and provide fire protection. The site has served as a field demonstration area for people interested in white pine ecosystem management. The study is described within the FERN network of sites on the Internet.
\end{abstract}

Key words: eastern white pine, Pinus strobus, natural regeneration, understory planting, multidisciplinary field research, forest research sites
Une etude sur une parcelle de 27 ha a ete entreprise en 1994 dans la Foret experimentale de Petawawa situee pres de Chalk River en Ontario, avec l'aide et l'appui des chercheurs locaux, des amenagistes et des techniciens forestiers. L'etude a ete concue pour etudier les effets des coupes partielles, de la preparation du sol et de la plantation en sous-etage dans des peuplements naturels de pin blanc. (Pinus strobus L.) Un design de blocs experimentaux repartis totalement au hasard a ete repete quatre fois. Trois eclaircies (temoin, une eclaircie par le haut, et deux eclaircies par le haut) et quatre traitements de preparation du sol (temoin, scarifiage, controle de la competition a l'aide de phytocide, et scarifiage suivi de controle de la competition a l'aide de phytocide) ont ete appliques. La regeneration naturelle, la survie et la croissance des semis plantes, la disponibilite des elements nutritifs dans le sol, ainsi que d'autres facteurs environnementaux ont ete evalues et enregistres. Les resultats preliminaires ont permis le developpement d'un nouveau guide sylvicole provincial et le prototype d'un systeme expert de prise de decision pour l'amenagement du pin blanc. Les activites de recherche sont evaluees et coordonnees avec les pratiques de terrain a chaque annee par l'entremise de l'elaboration d'ententes formelles de collaboration, de rencontres, d'ateliers conjoints et d'excursions techniques. Le personnel en place participe a la collecte des donnees sur le terrain et assure la protection contre le feu. Le site a servi de zone de demonstration pour les personnes interessees par l'amenagement des ecosystemes de pin blanc. L'etude est decrite parmi les sites du reseau FERN sur Internet.

Mots-cles : pin blanc de l'Est, Pinus strobus, regeneration naturelle, plantation en sous-etage, multidisciplinaire, recherche sur le terrain, site

\section{Introduction}

Eastern white pine (Pinus strobus L.) is an important tree species in eastern North America providing high-quality timber (Stiell 1985), wildlife habitat (Rogers and Linquist 1992, Naylor 1994), recreational opportunities (Tlusty 1992), and significant symbolic and spiritual values (Schroeder 1992). Natural regeneration is often unacceptably low both in Canada

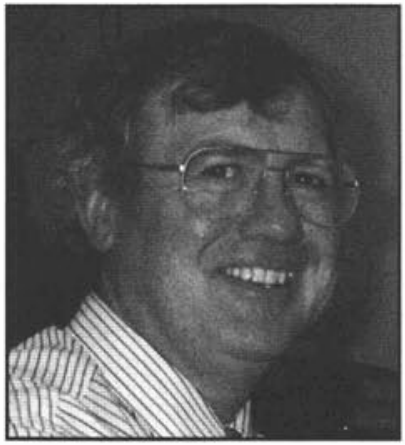

D. Burgess (Pinto 1992) and the United States (Leak et al. 1995). The methods required to manage forests to ensure the regeneration and

${ }^{1}$ Pacific Forestry Centre, 506 West Burnside Road, Victoria, B.C. V8Z 1M5. ${ }^{2}$ Great Lakes Forestry Centre, 1219 Queen Street East, Sault Ste. Marie, ON P6A 5M7.

${ }^{3}$ Ontario Ministry of Natural Resources, 3301 Trout Lake Rd., North Bay, ON P1B 6V2.

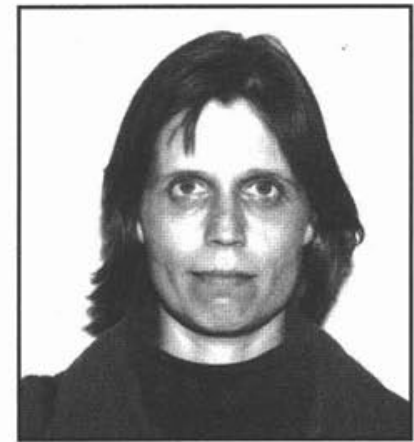

S. Wetzel

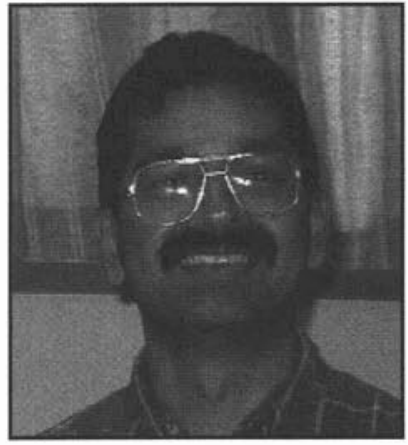

F. Pinto recruitment of white pine are complex (OMNR 1998). Relatively little is known about the physiology of eastern white pine (Wetzel and Burgess 1994) or its ability to regenerate and develop in managed stands (Hibbs and Bentley 1987).

Wild fire suppression programs and attacks by the white pine weevil (Pissodes strobi Peck) have had severe impacts on natural and artificial regeneration of eastern white pine. Its high value and the sheltering effect of residual trees against wee- 
vil attacks has encouraged the use of shelterwood systems in white pine management (Burgess 1996). Most pine stands in central Ontario, Canada are managed using a shelterwood system that requires managers to consider both plant adaptations and the effects of natural disturbances. The system involves the removal of trees that are considered most likely to be killed in natural disturbances. These trees are removed in two to three thinning operations. Some live cavity and mast trees are retained in earlier harvests, and also in the final harvest a few large, veteran trees are retained for added stand structure and benefits to wildlife (OMNR 1998).

Competition is a major problem on the better quality white pine sites and silvicultural techniques are needed to promote pine regeneration establishment and growth (Stiell et al. 1994). On competition-prone sites, seeding cuts are typically followed by site preparation. Mechanical scarification is common and may be followed by a herbicide treatment (OMNR 1998). Underplanting with pine may be necessary in poor seed years to supplement natural regeneration. Controversy continues about how eastern white pine forests should be regenerated and managed in light of the high, and sometimes conflicting, demands for their use (Quinby 1991, Carleton et al. 1996).

The objectives of this field study were to examine thinning and site preparation treatments under a shelterwood system in mature, natural white pine stands as methods for establishing and promoting early growth of pine regeneration and to investigate the causes of why differences in regeneration responses occurred. Natural and planted regeneration development, residual tree growth, nutrient availability and uptake comparisons, and changes in other major environmental factors such as microclimate and diversity/competition are being evaluated through time.

\section{Materials and Methods \\ Project Design and Establishment}

A forest cruise and soil survey were completed prior to treatment in three similar 110-year-old natural pine stands within the Petawawa Research Forest, Chalk River, Ontario, Canada $\left(45^{\circ} 57^{\prime} \mathrm{N}, 77^{\circ} 34^{\prime} \mathrm{W}\right)$. The total study area was 27 ha in size. Species composition was predominantly white pine, with $87.5 \%$ of the total basal area consisting of white and red pine (Pinus resinosa Ait.). The soils were acidic ( $\mathrm{pH} 3.8$ ) podzols and brunisols with textures ranging from coarse to fine sand. Soil depth varied but was $>1.2 \mathrm{~m}$ throughout most of the study area. The study site was classified as an ecosite type ES 11.2 within the central Ontario Forest Classification (FEC) System (Chambers et al. 1997).

A randomized block, split-plot design with four replicates was used. The four replicates or blocks were stratified on the basis of white pine basal area. Main treatment plots were 1 ha in size and surrounded by $25 \mathrm{~m}$ wide buffer areas. Main plot treatments were (1) thinning to one crown width between trees, (2) two crown widths between trees and (3) control (uncut) spacing. The tree marking was completed prior to harvesting by trained tree-markers. Trees selected for retention were healthy and vigorous and as evenly distributed as possible. A forest technician supervised logging activities during winter 1994. Logging crews used chain saws for tree felling and cable skidders. Approximately $62 \%$ of the total volume in the onecrown and $82 \%$ in the two-crown thinning were harvested. The site preparation treatments were applied randomly to sub-plots ( 0.25 ha each) plus 5- to 25 -m-wide buffers within the plots. The four site preparation treatments were (1) blade scarification, (2) brush control using herbicide, (3) blade scarification and brush control, (4) and untreated (control). Scarification was completed in August 1994. Vision ® (n-phosphonomethyl) was applied in September 1995 at standard rates. Half of each subplot was planted in spring 1995 with white pine container-grown seedlings at a $2 \mathrm{~m} \times 2 \mathrm{~m}$ spacing.

\section{Project Coordination}

The study was developed through close cooperation and input from a variety of people. Three study sites were planned initially: (1) Petawawa, (2) Parry Sound and (3) in the Eastern Ontario Model Forest. With the closure of the Petawawa National Forestry Institute the latter location was not included as a study site. The Parry Sound experiment is similar in design, but less intensively studied than the Petawawa experiment and is not discussed further here. Study activities were coordinated by staff from the Forest Productivity Project, Petawawa National Forestry Institute, Chalk River, Ontario. Science managers with the Ontario Ministry of Natural Resources, Science and Technical Unit, North Bay, Ontario and forest managers with the Algonquin Forest Authority, Pembroke, Ontario assisted with treatment selection. They helped to ensure that the knowledge and experience of forest managers was incorporated in the design and that research results would be usable in prescription and forest policy development.

\section{Project Funding}

Financial support was obtained from the Northern Ontario Development Agreement (NODA) and the CFS Forestry Practices Program (Green Plan) initially and later from NODA and the Forest Practices and Ecosystem Processes Networks of the Canadian Forest Service. Research proposals were evaluated and funded annually based on a competitive process. No long-term funding was available for the study.

Collaborative research agreements were developed that outlined annual work activities and the responsibilities of each agency. Some university researchers have expressed interest in using the study area. One Ph.D. student (Jean François Boucher, supervised by Professor Alison Munson) from Laval University is presently completing a thesis study on white pine seedling physiology using this experimental area.

\section{Project Sampling and Assessment}

The Forest Engineering Institute of Canada (FERIC, Pointe Claire, Quebec, Canada) contributed by assessing logging productivity and the damage to residual trees. The scarification treatment was characterized by CFS staff determining the length of transects covered by slash or exposed mineral soil. Windthrown trees were recorded.

Tree regeneration surveys that assessed both seedling numbers and stocking were completed each fall. Furthermore, a sample of natural and planted white pine seedlings were harvested and characterized each year. Mixed-bed resin bags (IONAC NM-60, Sybron Chemicals Inc., Birmingham, New Jersey) were set out each spring and used to give an indication of relative nutrient availability. In the fall, when white pine seedlings were harvested, resin bags were retrieved. Nutrients within resin bags and seedling tissue samples were analyzed for nutrient levels using standard procedures (Kalra and Maynard 1991). 
Soil temperature and water potential, photosynthetically active radiation (PAR), air temperature and relative humidity, and rainfall were measured throughout the growing season using field dataloggers and suitable probes (Campbell Scientific, Logan UT) within two complete blocks. Analyses of variance (ANOVA) were conducted to examine treatment effects and to test for major differences among treatments.

While the short-term objectives of the study were to investigate factors affecting regeneration establishment and early development, the experiment was set up to address longer-term goals. These include investigations on the growth and development of the residual pine trees.

\section{Results and Discussion Project Deliverables}

Project deliverables are outlined annually within research proposals, collaborative agreements and CFS study work plans. The site is being promoted through publication of scientific and technical papers, presentations at conferences and workshops, field tours and demonstrations and a study description is included in the FERNS web site. Several activities are planned each year to communicate results to target audiences. Feedback is obtained through scientific peer review and direct contact with resource managers at workshops and in the field. Some early results from the study have been published elsewhere (Burgess et al. 1999). Various species and processes within the ecosystem are not being investigated and new collaborators are welcome.

\section{Project Pitfalls}

No long-term funding is available and the project faces an uncertain future. The closure of the Petawawa National Forestry Institute was a major setback as now there are no research scientists based on-site and plans to establish similar studies elsewhere were stopped or delayed. Nevertheless, this project has continued and has received funding each year since 1993. It is particularly helpful having some CFS staff on-site who are familiar with the project. If starting the project again, closer collaboration would be sought with researchers elsewhere, including scientists and resources managers in the central and northeastern United States. Further, efforts would be made to include a half-crown between trees thinning treatment (which is the operational norm in Ontario), and prescribed burning as a pre-harvest site preparation treatment.

\section{Conclusions}

1. This project was developed with partners who helped ensure that the study addressed important scientific (causative factors) and management (mainly silvicultural) issues.

2 . The multidisciplinary group of scientists, foresters and technicians involved in planning, design and assessment added greater depth and scope to the study.

3. Use of an appropriate experimental design allowed statistical testing of the experimental results. While this should be the norm, it is not always practised.

4. A number of short- and long-term goals were recognized and included in the project. They have helped provide some useful early results (such as the use of scarification in a good seed year) and ensured that longer-term results will also be helpful and forthcoming.

5. Deliverables were planned to ensure that clients were informed of project results through written papers, participation in meetings, leading of field tours and maintaining up-to-date information on the study within the FERNS web site.

\section{Acknowledgements}

We acknowledge all others involved in planning and setting up this study, particularly the following people: Dr. Jeff Baldock who is now a research scientist with CSIRO Land and Water, Glen Osmond, SA 5064, Australia, senior technicians Mr. Craig Robinson, Chalk River, Ontario and Mr. Gord Brand, Sault Ste. Marie, Ontario, both with the Canadian Forest Service and Ms. Brenda Chambers, Forest Ecosystem Classification Program Leader, Southeastern Science Section, North Bay, Ontario with the Ontario Ministry of Natural Resources.

\section{References}

Burgess, D., S. Wetzel, and J.A. Baldock. 1999. White/red pine stand response to partial cutting and site preparation. J. Sustainable Forestry. (in press).

Burgess, D. 1996. Forests of the Menominee - a commitment to sustainable forestry. For. Chron. 72: 268-275.

Carleton, T.J., P.F. Maycock, R. Arnup, and A.M. Gordon. 1996. In situ regeneration of Pinus strobus and $P$. resinosa in the Great Lakes forest communities of Canada. J. Vegetation Sci. 7: 431-444. Chambers, B.A., B.J. Naylor, J. Nieppola, B. Merchant, and P. Uhlig. 1997. Field guide to forest ecosystems of central Ontario. Ont. Min. Natural Resources, Ontario. SCSS Field Guide FG-01. 200 p. Hibbs, D.E. and W.R. Bentley. 1987. White pine management: Volume and value growth. North. J. Appl. For. 4: 197-201.

Kalra, Y.P. and D.G. Maynard. 1991. Methods for forest soil and plant analysis, Forestry Canada, Edmonton, Alberta. Information Report NOR-X-319. 116 p.

Leak, W.B., J.B. Cullen, and T.S. Frieswyk. 1995. Dynamics of white pine in New England. USDA For. Serv. Ne. Res. Pap. 699.

Naylor, B.J. 1994. Managing wildlife habitat in red pine and white pine forests of central Ontario. For. Chron. 70: 411-419.

Pinto, F. 1992. Silvicultural practices in Ontario's white pine forests. In R.A. Stine and M.J. Baughman (eds.). Proc. White pine symposium: history, ecology, policy and management, Sept. 16-18, 1992, Duluth, Mn. pp. 170-178. Dept. For. Resources, Univ. Minnesota, St. Paul, MN.

OMNR. 1998. A silvicultural guide for the Great Lakes-St. Lawrence conifer forest in Ontario. Version 1.1, Ont. Min. Nat. Resour. Queen's Printer for Ontario. Toronto, ON. 424 p.

Quinby, P.E. 1991. Self-replacement in old-growth white pine forests of Temogami, Ontario. For. Ecol. Mgt. 41: 95-109.

Rogers, L.L. and E.L. Lindquist. 1992. Supercanopy white pine and wildlife. In R.A. Stine and M.J. Baughman (eds.). Proc. White Pine Symposium: History, Ecology, Policy and Management, University of Minnesota. Symposium NR-BU-6044. pp. 44-53.

Schroeder, H.W. 1992. The tree of peace: symbolic and spiritual values of the white pine. In R.A. Stine and M.J. Baughman (eds.). Proc. White Pine Symposium: History, Ecology, Policy and Management, University of Minnesota. Symposium NR-BU-6044. pp. 7383.

Stiell, W.M. 1985. Silviculture of eastern white pine. In Proc. Entomological Soc. Ont., Supplement to Vol. 116: 95-107.

Stiell, W.M., C.F. Robinson, and D. Burgess. 1994. 20-year growth of white pine following a commercial improvement cut in pine mixedwoods. For. Chron. 70: 385-394.

Tlusty, W.G. 1992. Visual and recreational values of eastern white pine. In R.A. Stine and M.J. Baughman (eds.). Proc. White Pine Symposium: History, Ecology, Policy and Management, University of Minnesota. Symposium NR-BU-6044. pp. 84-98. 